\title{
SANITARY ANALYSIS OF Lentinula edodes (SHIITAKE) MUSHROOMS COMMERCIALIZED IN CAMPOS DOS GOYTACAZES, RJ
}

\author{
Maria Aparecida Vieira Mussi-Dias ${ }^{1 *}$; Larissa Pacheco Ferreira ${ }^{2}$; Fabíola Teixeira \\ Azevedo $^{3}$; Pedro Henrique Dias dos Santos ${ }^{4}$ \& Lívia Marini Palma
}

\begin{abstract}
RESUMO
MUSSI-DIAS, M.A.V.; FERREIRA, L.P.; AZEVEDO, F.T.; SANTOS, P.H.D.; PALMA, L.M. Análise sanitária de cogumelos Lentinula edodes (shiitake) comercializados em Campos dos Goytacazes, RJ. Perspectivas Online: Biológicas \& Saúde, v.10, n.32, p.1-15, 2020.

Os cogumelos são alimentos milenares que compõem a dieta de populações de várias partes do mundo e, no Brasil, embora o consumo ainda seja modesto, quando comparado a outros países, tem havido um aumento significativo na procura. Os cogumelos comestíveis apresentam qualidades nutricionais e funcionais atrativas, dentre elas: proteínas de boa qualidade e baixo valor calórico. Algumas espécies de cogumelos, como Shiitake, quando consumidos frescos não passam por processos de sanitização para que não sofram alterações de textura, sabor e aroma. Assim, em função da variação da origem, forma de manejo e produção, não se sabe se este produto está livre de contaminações por microrganismos

neste trabalho analisar a qualidade sanitária de Shiitake in natura, comercializadas no município de Campos dos Goytacazes, RJ. Amostras de dois produtores distintos foram analisadas para a detecção de coliformes totais e termotolerantes, Salmonella spp., fungos e nematoides associados. Os resultados foram negativos para coliformes totais $\mathrm{e}$ termotolerantes, bem como para nematoides. No entanto, foi detectada a presença de Salmonella spp. em duas amostras de um dos produtores, sendo estas consideradas impróprias para $\mathrm{o}$ consumo por representarem risco ao consumidor. Também foram encontrados fungos e outras bactérias deterioradoras contaminando o produto.
\end{abstract} patogênicos. Dessa forma, objetivou-se

Palavras-chave: Coliformes; Salmonella; Fungos; Nematoides; Análise microbiológica. 


\begin{abstract}
Mushrooms are millennial foods that make up the diet of populations in various parts of the world, and in Brazil, although consumption is still modest, compared to other countries, there has been a significant increase in demand. Edible mushrooms have attractive nutritional and functional qualities, among them: proteins of good quality and low caloric value. Some mushroom species, such as Shiitake, when consumed fresh do not undergo sanitization processes in order not to modify their texture, taste and aroma. Thus, due to the variation of origin, management and production, it is not possible to know if this product is free of
\end{abstract}

ABSTRACT

contamination by pathogenic microorganisms. Thus, the objective of this work was to analyze the sanitary quality of Shiitake in natura, commercialized in the municipality of Campos dos Goytacazes, RJ. Samples from two different producers were analyzed for the detection of total and thermotolerant coliforms, Salmonela spp., Fungi and associated nematodes. The results were negative for total and thermotolerant coliforms, as well as for nematodes. However, it was detected the presence of Salmonela spp. in two samples of one of the producers, which make them unfit for human consumption because they represent a risk for the consumer. Fungi were also found contaminating the product.

Keywords: Coliform; Salmonella; Fungi; Nematodes; Microbiological analysis.

\footnotetext{
${ }^{1}$ Nutritionist. Redentor College, Campos - Rua Dr. Beda, 112, Turf Clube, Campos dos Goytacazes, RJ, CEP: 28025-110, Brasil,

${ }^{2}$ Master in Vegetable Production (Food Technology). Redentor College, Campos.

${ }^{3}$ Doctor in Food Science and Technology. Redentor College, Campos.

${ }^{4}$ Doctor in Vegetable Production (Phytosanitarity) - Phytosanitarity Clinic of the Northern Rio de Janeiro State University Darcy Ribeiro - UENF - Entomology and Phytopathology Laboratory - LEF/CCTA - Av. Alberto Lamego, 2000, Parque Califórnia, Campos dos Goytacazes, RJ, CEP: 28013-602, Brasil.

${ }^{5}$ Doctor in Biosciences and Biotechnology. Redentor College, Campos.

(*) e-mail: (*) e-mail: aparecidavmd@ gmail.com

Data de recebimento: 20/11/2019. Aceito para aprovação: 19/02/2020
} 


\section{INTRODUCTION}

Mushrooms have been eaten for millennia and have occupied a prominent position in the diets of Asian, African and European peoples. For Romans and Egyptians, they were considered divine food and consumed only in special moments. For Asians peoples, such food was - and still is - considered a longevity source. Besides those, some other peoples made use of mushrooms in religious rituals because they were given another fundamental cultural significance, that is: they were considered not only food for the body, but also for the spirit. They were taken, in such cases, as food-drugs for their hallucinogenic effects (ALEXOPOULOS et al., 1996; CARNEIRO, 2005; FURLANI, 2005).

Today, mushrooms still have a prominent role in feeding populations around the world, being highly appreciated both in high gastronomy and in popular dishes. In Brazil, consumption of such delicacy is still modest in comparison to other countries, but it has exhibited a continuous, significant increase: consumption increased from $70 \mathrm{~g}$ per person/year in 2007 to 288 g per person/year in 2017 (ROSA, 2007; EMBRAPA, 2017).

Demand for such products has increased due to several factors, and the most evident are globalization; gastronomic trends; and search for healthier, pesticide-free food items, that is: besides nutritional objectives, there have also been functional objectives such as the protection of the subjects' immunological system. The last, but not the least reason we will mention is the perceivable worldwide growth of a population that shares, as their lives' philosophy, the consumption of healthy food items produced with low environmental impact, and who are against the rearing and inhumane slaughtering of animals (HAAS, 2016; BERNARDI et al., 2010; MIWA, 2016).

Mushrooms are considered low calorie foods that still are a good source of vitamins and minerals, with high contents of Fe, Mg, Mn, Mo e Zn (GONÇALVES, 2012). Rich in good quality proteins, once they carry all essential amino acids, mushrooms can be considered an excellent protein source option, also offering the advantage of having predominantly polyunsaturated fatty acids $(70 \%-80 \%)$. Such hypolipemic nature makes them easy to digest (AMAZONAS e SIQUEIRA, 2003).

According to ANVISA (Brazilian Health Regulatory Agency), an edible mushroom is a product obtained from an edible fungus species traditionally used as a food item, and it can be desiccated, entire, fragmented, grounded or pickled, submitted to drying, smoking, cooking, salting, fermenting or undergo through any other technological processes considered safe for food production (ANVISA, 2005).

Brazilian mushroom production has not been formalized yet and it is not accounted by the producing countries - despite mushrooms recent noticeable growing consumption, which obviously denotes an increase in their production and marketing (ANPC, 2017). Current consumption increase has been attributed to today's greater dissemination of mushrooms' nutritional/functional value, and also to the fact that prices have become a little more accessible to the general population.

In Brazil, the most widely cultivated and consumed species are: Agaricus bisporus, known as Paris champignon; Lentinus edodes, Shiitake; Pleurotus spp. and its variations, Shimeji or Hiratake; Oudemansiella canarii and; Agaricus blasei, the mushroom of the sun (URBEN, 2004; DUPRAT, 2008; RUEGGER et al., 2001; ORTIZ et al., 2007). 
For all cultivated species, fructification time depends on the quality of both the fungus inoculum and compost (substrate) used for cultivation, as well as on suitable environmental conditions. After mushroom formation, manual harvesting occurs daily for several days, even months. After being harvested, mushrooms are washed to remove soil remnants and any dirt, mainly on the stipe. They are, then, selected according to size, texture, appearance and aroma (ROSA, 2007). However, all cultivated species do not undergo the same harvesting, packing and storing processes.

In most production sites, cultivation is still performed in a rudimentary way, generally following subsistence farming techniques, and with little information about sanitary quality. Once interest in mushrooms has increased because they are rich in proteins, lipids and fibers, but also because they are natural and good quality food items, their production itself has become a concern for food and health fields' professionals (FURLANI e GODOY, 2007): professionals who have demanded proof of the real sanitary quality of marketed mushrooms.

Some mushroom types can be processed to be used in natura or dehydrated, pickled, bottled, precooked or sliced, grounded, and encapsulated as pills. However, some species must not be washed, once washing makes them lose their aroma and flavor; thereby, they lose their marketing desirable characteristics. Thus, those species must be packed immediately after being harvested without any processing (ROSA, 2007).

Shiitake is one of those mushrooms marketed in natura: it does not undergo any sanitization process before being available for consumption. Very little is known about the sanitary quality of this product when marketed; therefore, a current legal-based microbiological investigation becomes necessary.

This paper aimed to assess the hygienic-sanitary conditions of in natura Shiitake mushrooms obtained from two different producers and marketed in the municipality of Campos dos Goytacazes, RJ.

\section{METHODOLOGY}

\subsection{Sample collection}

Samples were obtained in two different horticulture retailers in the municipality of Campos dos Goytacazes, RJ. Samples came from two different suppliers (Figure 1) and five samples from each supplier were collected. We considered one sample each styrofoam tray, covered with transparent PVC film, containing 200-250 g of properly labeled mushrooms without any apparent damage and within the expiration date.

After collection, samples were stored at approximately $5{ }^{\circ} \mathrm{C}$ temperature for two days until the analyses. Before opening the trays, they were cleaned with paper towels dipped in alcohol $70 \%$. 


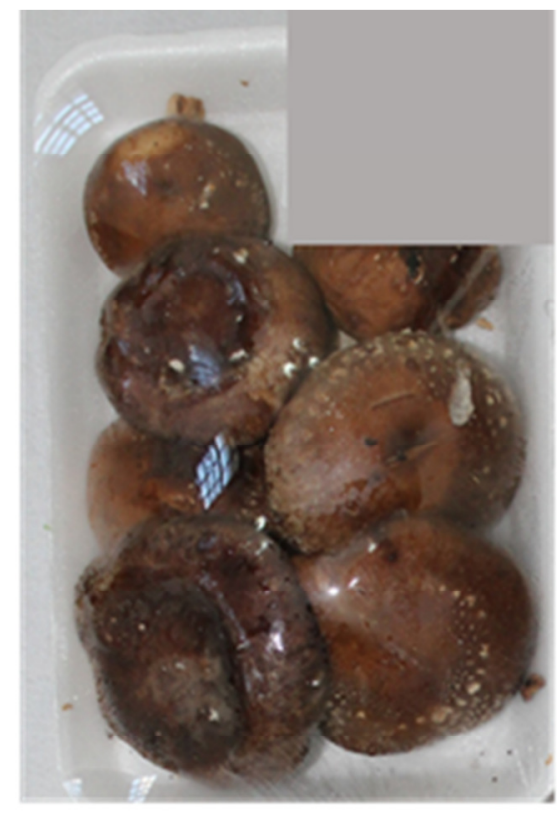

Producer 1

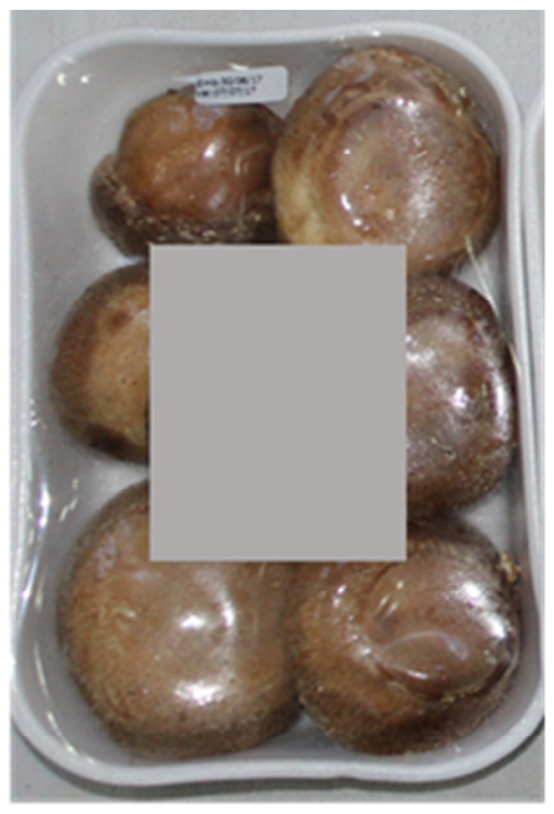

Producer 2

Figure 1: Shiitake musshroom samples from two different producers marketed in Campos dos Goytacazes, RJ.

\subsection{Total and thermotolerant coliforms detection}

From each sample tray, considered as a sample unit, $25 \mathrm{~g}$ mushroom portions were taken, aseptically chopped and placed into a sterilized Becker containing $225 \mathrm{~mL}$ of $0.1 \%$ peptoned water. Suspension was crushed with a mixer (previously sanitized with alcohol $70 \%$ for 15 minutes), and then directed to serial dilutions in test tubes containing $9 \mathrm{~mL}$ of $0.1 \%$ peptoned water. Diutions ranged from $10^{-1}$ to $10^{-4}$.

In order to determine the most likely number of samples' contaminants (MLN/g), the multiple tube method was used (SILVA et al., 2007). The presumptive test for coliforms was performed by using $9 \mathrm{~mL}$ of Lauryl Sulfate Tryptose Broth (LST), an inverted Durham tube and $1 \mathrm{~mL}$ of dilutes $10^{-1}, 10^{-2}, 10^{-3}$ and $10^{-4}$ from each sample. All tubes were incubated in an oven at $37^{\circ} \mathrm{C}$ from 24 to 48 hours (CHAGAS e FERNANDES, 2019). After such period, a positive result was considered for those tubes displaying presence of gas in the Durham tube and medium cloudiness.

A confirmatory test for coliforms was performed by transfering rates from tubes considered positive in presumptive tests, by platinum handle, into other tubes containing 9 $\mathrm{mL}$ of Brilliant Green Bile Broth (BGBB), also containing inverted Durham tubes. These tubes were incubated at $35{ }^{\circ} \mathrm{C}$ from 24 to 48 horas. Tubes were considered positive for coliforms when production of gas, as indicated by the Durham tube, and medium clouding were noticed.

Assessment of thermotolerant coliforms presence was performed from the bacterial growth in the presumptive tests, when rates were transferred from LST tubes into tubes containing $9 \mathrm{~mL}$ of Escherichia coli Broth (EC) and inverted Durham tubes. Incubation was performed in hot water at $45{ }^{\circ} \mathrm{C}$ for 48 hours, and tubes displaying presence of gas and clouding were considered to be positive for the presence of thermotolerant coliforms. 
Samples obtained from a toilet rim were used as positive controls.

\subsection{Salmonella spp. detection}

Samples for analyses of Salmonella spp. were prepared in the same way of the initial dilutions for the detection of coliforms. A portion of $25 \mathrm{~g}$ of each mushroom sample was obtained and placed into a sterilized Becker containing $225 \mathrm{~mL}$ of homogenized $0.1 \%$ buffered peptone water which was incubated at a $35{ }^{\circ} \mathrm{C}$ for 24 hours, what consisted in one sample's pre-enrichment step.

Subsequently, aliquots of $1 \mathrm{~mL}$ were transferred in triplicate into tubes containing 10 $\mathrm{mL}$ of tetrathionate broth, a broth for selective enrichment of those samples whose gas production was positive, but this time incubation was at $37^{\circ} \mathrm{C}$ for 24 horas in hot water.

Sequentially, with the aid of a platinum needle, one sample was taken out of each tetrathionate tube and sowed depth in the agar and also streaked on agar slant tubes containing Triple Sugar Iron (TSI) medium. Then, incubation occurred from 35 to $37^{\circ} \mathrm{C}$ for 24 hours.

Samples taken from the tetrathionate broth were also sowed, with the aid of a platinum wire loop, on the surfaces of Petri dishes containing Brilliant Green (BG) Agar selective medium and Salmonella Shigella Agar (SS). Samples were then incubated at $37^{\circ} \mathrm{C}$ from 24 to 48 hours in a microbiological incubator.

Growth media used for Salmonella spp. detection are selective and presumptive. Antigenic characterization is required to confirm the presence of Salmonella spp. species.

\subsection{Fungi and other associated bacteria detection}

Random mushroom fragments were collected from each sample tray (Figura 2A) and used for indirect fungi isolation. Each fragment was sequentially disinfected in alcohol $70 \%$ (1 min.), sodium hypochlorite $1 \%$ (1 min.) and sterile destilled water according to Freire et al. (2016) modified. Excess water was removed by filter paper and esch fragment was deposited, in an equidistant position, in a Petri dish containing potato dextrose agar (PDA) medium (DHINGRA e SINCLAIR, 1995). Five fragments per dish were sowed (Figura 2B) in a total of 4 repetitions for each mushroom sample. Dishes were then stored in a germination chamber at $27{ }^{\circ} \mathrm{C}$ with a 12-hour photoperiod.

At the same time, a wet chamber was prepared with various fragments from the same sample (Figura 2C), under the same temperature and photoperiod. This test was designed to enable parallel fungi detection in the fresh material in order to compare the results in case of no fungi growing in the externally disinfested samples.

After incubating for seven days, and with development of colonies, slides with fragments from each fungus mycelium were prepared and fungi were identified through light microscopy by spore morphology using descriptive keys regarding the phyla they belonged to (SEIFERT et al., 2011).

For sample-associated bacteria detection, the same methodology used for indirect isolation was employed. However, the medium used was 523 or Kado medium (KADO e 
HESKETT, 1970): commonly used for phytopathogenic bacteria isolation and characterization. Gender identification was performed through dyeing, physical and biochemmical methods (ROMEIRO, 2001).
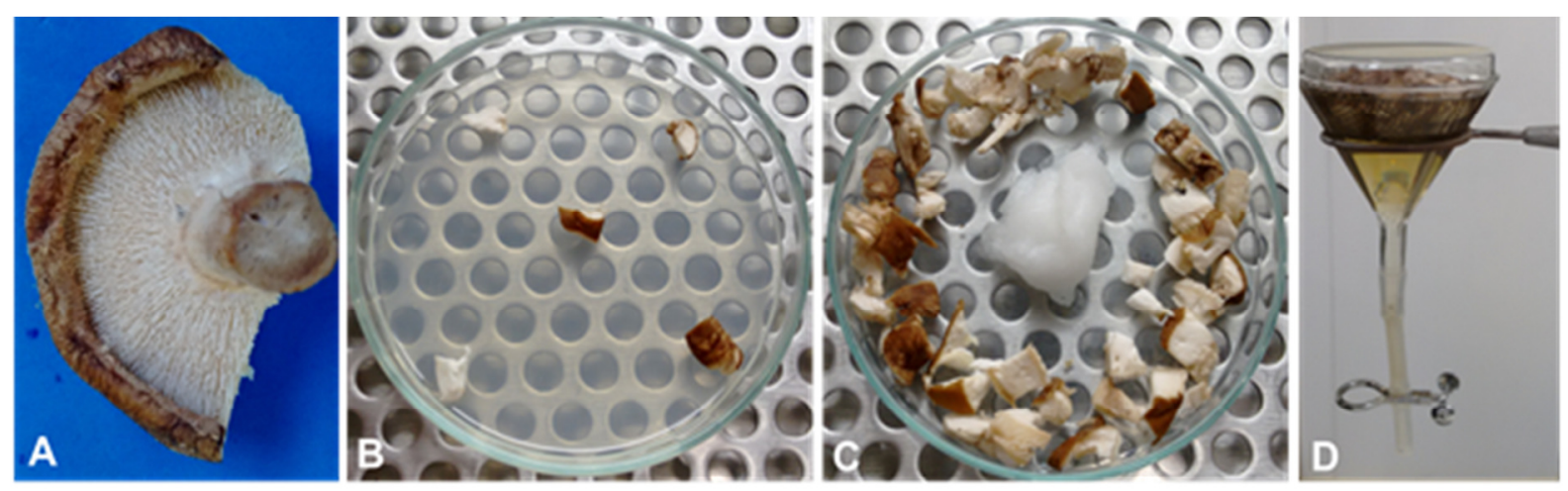

Figure 2: Shiitake mushroom processing for fungi and associated nematodes detection. A) Basidiocarp section, as seen from below, exhibiting mushrooms' gills or hymenium;

B) Disinfested fragments placed on cuture medium for fungi indirect isolation;

C) Undisinfested fragments deposited in wet chamber for the appearance of signs indicating the direct isolation of other fungi; D) Fragments deposited in a Baermann funnel for nematodes extraction through water decantation.

\subsection{Nematodes detection}

Two extraction methods were used in order to detect living or dead nematodes in mushrooms samples. The first one, using the Baermann funnel, consisted in fragmenting the mushrooms and depositing them in a funnel containing water and a sieve where nematodes were collected by decantation after 24 hours (Figura 2D). The second method was performed by centrifugation in sucrose solution and consisted in grinding mushroom fragments in a blender and passing the solution through 60 and 400 mesh sieves. All material retained in the 400 mesh sieve was retrieved, centrifugated in water and, later, in sucrose solution. Due to density differences, nematodes were collected on the sieve and taken to the microscope for morphological identification (TIHOHOD, 1993).

\section{RESULTS AND DISCUSSION}

Shiitake mushrooms marketed in Campos dos Goytacazes, RJ, did not exhibit coliform contamination. None of the ten samples provided by both producers and analyzed in this research displayed gas production or clouding in the lactated medium (Figura 3). In this case, there was no need to go on with the analyses; only the presumptive test was performed (VEIGA et al., 2013).

Results obtained for both total and thermotolerant coliforms were deemed within normal standards established by ANVISA's RDC 12, January 2nd, 2001 (ANVISA, 2001) because they exhibited satisfactory hygienic-sanitary conditions for human consumption, that is: they displayed coliform analytical results below established limits $\left(2 \times 10^{3} \mathrm{UFC} / \mathrm{g}\right)$ for in natura mushrooms representative samples. 
Although the presence of thermotolerant coliforms must not be tolerated for certain types of food items, such as meat, for other ones there are variable limits which provide safer information about the produces' higienic conditons. Thus, this offers the best indication of any occasional enteropathogen presence (MOURA et al., 2007).

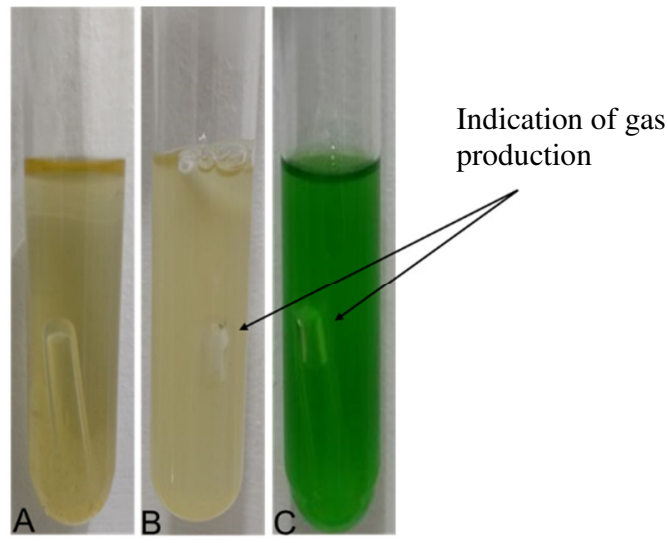

Figure 3: Shiitake samples fecal and thermotolerant coliforms growth assessment. A) Lactated broth displaying neither fermentation nor gas production (no growth was observed); B) Lactated broth displaying fermentation and gas production (control), e C) Brilliant Green Broth displaying growth (control).

There are virtually no studies in the literature on marketed fresh mushrooms sanitary conditions. In the specific case of $L$. edodes, studies focus on the mushrooms' own constituent substances. Some focus on their beneficial, nutritional or pharmacological effects for mankind (BITO et al., 2014; FINIMUNDY et al., 2014); others on their harmful effects for other biological targets, including their antimicrobial effect for $E$. coli (SÁNCHEZ-MINUTTI et al., 2016). Perhaps that is the reason why studies on edible mushrooms sanitary quality have been neglected.

Once no coliforms were detected in the samples analyzed by this research, we suggest that other studies collect samples from a wider sample range, provided by a larger number of producers from different regions of the country, in order to access an ampler panorama of the quality of in natura Shiitake mushrooms available throughout the country.

Analyses were conducted to determine the presence of Salmonella spp. Samples from one of the two producers exhibited negative results. However, from the analyses of the other producer's five samples, it was noticed that two exhibited positive results for such bacteria (Figure 4).

Regarding reference standards for in natura mushrooms, the presence of Salmonella spp. in a 25-gram mushroom sample can not be accepted (ANVISA, 2001). In such case, the sample is deemed inadequate for human consumption.

According to Paulo (2005), salmonellas are considered potentially pathogenic for humans and they exclusively come into human organisms orally. Although its difusion is limited to just those who ingest contaminated food or water, analyses of those food items for salmonella detection is of utmost importance in order to establish consumption standards for them (MAPA, 2005). It happens because clinical complications and fatalities have been attributed to those bacteria - and salmonellosis has been considered one of mankind's main foodborne infections (FBI) throughout the world: what also forces a considerable increase in 
public expenditures on Health (KUSHIDA, 2005).
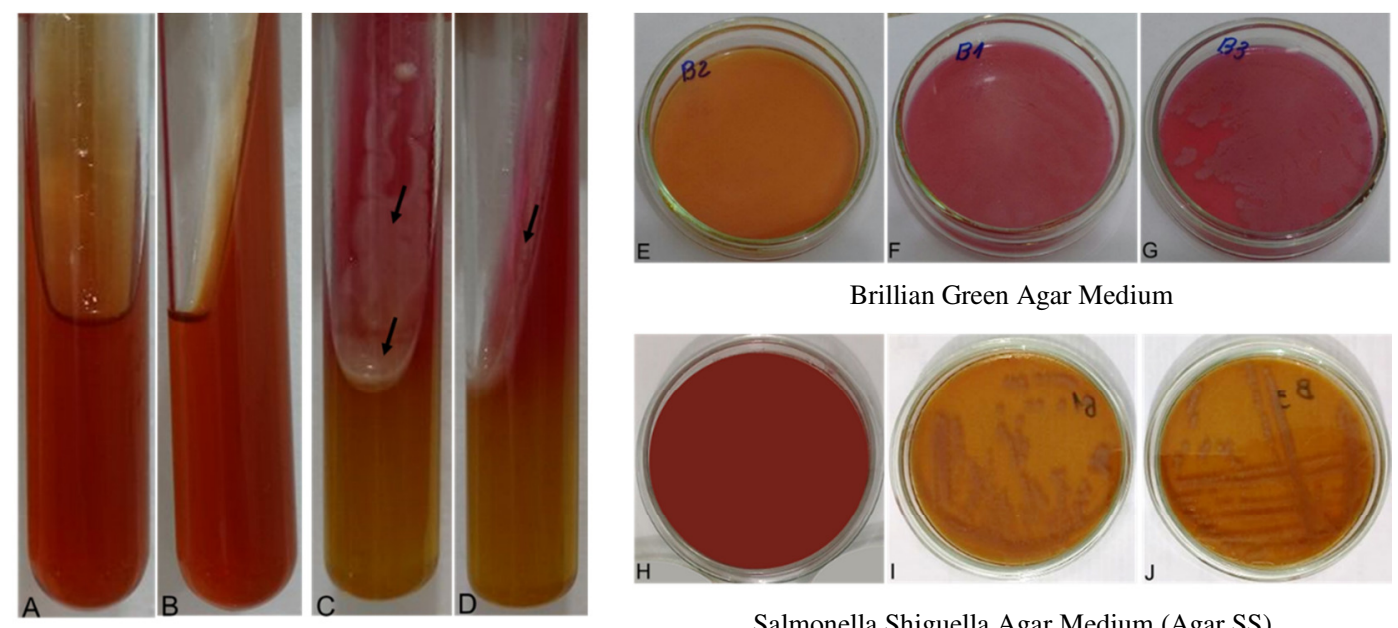

Brillian Green Agar Medium

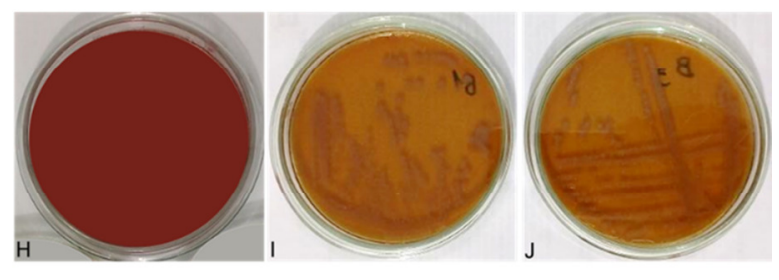

Salmonella Shiguella Agar Medium (Agar SS)

Figure 4: Agar slant test tubes with TSI medium and Petri dishes with media for Salmonella ssp. analyses. A and B) Negative result for in natura Shiitake mushrooms samples; C and D) Positive result exhibiting medium color alteration. Arrows indicate bacterial growth on the surface; $\mathrm{E}$ and $\mathrm{H}$ ) Absence of growth and natural media colors;

F, G, I e J) Presence of growth and culture media color alteration.

Great food variety can be contaminated by these bacteria: meat, eggs, milk and its derivatives, sea food, sweets, fruits and vegetables after minimum processing. Such contamination may occur due to inadequate temperatue control, improper handling practices or by contact between raw items and processed ones (SURESH et al., 2006; UKUKU, 2006 apud BORGES, 2010) - mushrooms included.

Other fungi and bacteria were found in association with in natura mushrooms (Figure 5). The fungi identified were Aspergillus niger, Trichoderma sp. and Fusarium sp.; and the bacteria were Xanthomonas sp. and Erwinia sp. However, no nematodes were observed in the samples. Such fungi are generally associated to the environment and to plant material decomposition. Aspergillus and Fusarium cause post-harvesting rotting and are frequently related to storaging and marketing losses. Trichoderma may grow on substrates used for mushrooms cultivation even after the substrate has been disinfested or sterilized, and compete for medium nutrients. Although such fungi are of a secondary importance, when edible mushrooms shelf-lifespan is concerned, one must pay attention to the fact that some species produce mycotoxins (SOUZA, et al., 2004) that might endanger consumption and call attention to a sanitary problem.

Substrate contamination may occur due to the presence of several organisms, including viruses, bacteria, nematodes, insects and mites - and they may be carried along with the marketed products. Insect attack is one of the problems mushrooms producers have faced. It may happen either in the mycelium growing substrate or during basidiocarp formation. According to Barreto et al. (2002), in several Brazilian states, Shiitake production areas have registered the occurrence of beattles, flies, ants and moths.

Generally, Trichoderma species can grow on substrates used for mushrooms cultivation even after the substrate has been disinfested or sterilized. Then, the species grows 
competing for substrate nutrients and becomes a contaminating species.
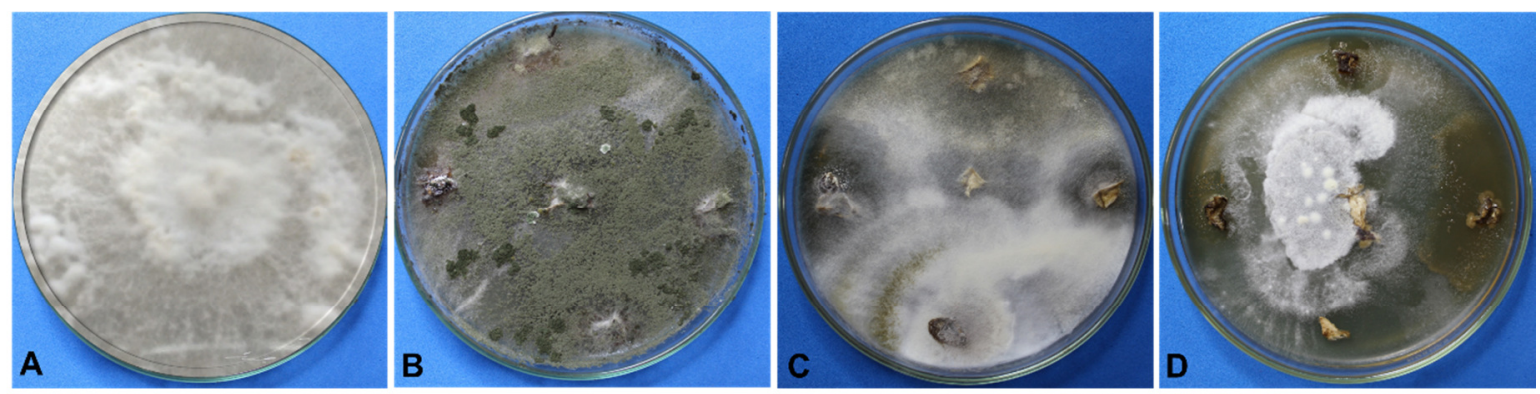

Figure 5: Isolation of Lentinula edodes (Shiitake) and associated fungi and bacteria in culture media. A) Pure L. edodes culture filamentous growth; B and C) Trichoderma sp. and Fusarium sp. fungi isolated from fragments of commercial samples of the edible mushroom;

D) L. edodes growth upon fragment positioned in the center of the dish and contaminant degrading bacterial growth upon peripheral fragments.

In many Brazilian mushroom producing farms, product is hand-harvested and all necessary care is not taken to avoid contamination either by soil or by substrate (BONONI et al., 1995). In Shiitake's case, the production is harvested by cutting through the stipe's base and immediate packing for sale. Mushrooms do not undergo any washing process which could eliminate whatever dirt they might carry on. This also means they are not immersed in chlorinated water to eliminate surface contaminants, once such processes will alter the species' odor and flavor characteristics (ROSA, 2007). This is why marketing Shiitake in natura demands special attention.

Actions fostering producers and workers sanitary education and adequate personal hygiene habits are recommended, along the whole productive process, as strategies to prevent Salmonella spp. occurrence and to keep a high quality standard for in natura marketed mushrooms (BORGES, 2010). Priority must be given to care on managing cultivation, using potable water for irrigation, watering logs properly, preparing the substrate, and moistening the environment. Besides, pests and vectors integrated control must include installation of nets on ventilation ducts whenever cultivation is done in an open space - once Shiitake is usually cultivated in shady or forest areas, in a more natural ambient (BETT, 2016). Special care must also be taken during all processing steps, from mushroom harvest, preparation and packing to produce storage, transport and distribution (MODA, 2008).

Post-harvesting mushrooms cooling, alone, does not prevent Salmonella spp. Bacteria of this genus are capable of surviving in freezing temperatures, as reported by Santos et al. (2000) in studies on frozen chiken carcasses.

Mushrooms in natura are highly perishable food items; therefore, they demand a shorter time period between production and consumption, no matter how many preservation techniques are employed to increase this time lapse.

When results are examined as a whole, as far as microbiological analyses for coliforms and Salmonella spp. are concerned, there was no relation between the two pathogenic agents presence in studied mushrooms. One hypothesis to explain coliforms absence in the examined samples may be a good hygienic-sanitary quality offered by the 
producers during the production processes and afterwards, by the harvesting, packing and marketing teams. By the other hand, the presence of Salmonella spp. in some samples indicates that there is an entrance door for such bacteria no matter the cultivation process: either in natural forested areas or in a shady environment. In both cases, Salmonella spp. might be introduced into the cultivation by small animals as reptiles, rodents, birds and mammals, as well as by insects or by the use of contaminated water (BARRETO, et al., 2002; MOURA et al., 2007) - just as it might happen regarding other fungi and bacteria like the contaminants found in this research.

Furthermore, we cannot discard the possibility that differences between samples, regarding the sample type, examined product and detection methods, might have provoked the differences found in our results (CAVADA et al., 2010).

Finally, food inspection and surveillance activities have, as their ultimate objective, the control and prevention of pathogenic bacteria occurrence in food items, besides fostering good handling practices along the entire food productive processes. Therefore, as far as publicly established microbiological standards are concerned, the production and/or marketing of Shiitake mushrooms in natura demands intervention by the sanitary surveillance governmental department.

\section{CONCLUSIONS}

The microbiological analyses carried out by sampling Shiitake mushrooms commercialized in the municipality of Campos dos Goytacazes, RJ, from two different producers, did not detect the presence of total or thermotolerant coliforms. However, presence of bacteria from the genus Salmonella was detected in samples from one producer. It indicates that such material was deemed improper for human consumption once it constitutes a risk factor for public health. Furthermore, fungi such as Trichoderma sp., Aspergillus niger and Fusarium sp. and bacteria such as Xanthomonas sp. and Erwinia sp. were detected and considered, in relation to the marketed mushrooms, as contaminant and degrader elements.

\section{REFERENCES}

ALEXOPOULOS, C.J.; MIMS, C.W.; BLACKWELL, M. Introductory Mycology. 4th ed. John Wiley, New York. 1996. 870p.

AMAZONAS, M.A.L.A.; SIQUEIRA, P. Champignon do Brasil (Agaricus brasiliensis): ciência, saúde e sabor. EMBRAPA Florestas (Documentos, 85), 2003. 45p.

ANPC - ASSOCIAÇÃO NACIONAL DOS PRODUTORES DE COGUMELOS. Cogumelos (2013). Disponível em: https://www.anpccogumelos.org/cogumelos. Acesso em: 15 jun. 2017.

ANVISA - AGÊNCIA NACIONAL DE VIGILÂNCIA SANITÁRIA. Resolução RDC no 272 - "Regulamento Técnico Para Produtos De Vegetais, Produtos De Frutas E Cogumelos Comestíveis". Publicação: D.O.U. - Diário Oficial da União; Poder Executivo, de 23 de setembro de 2005.

ANVISA - AGÊNCIA NACIONAL DE VIGILÂNCIA SANITÁRIA. Resolução RDC no 12

Persp. online: biol. \& saúde, Campos dos Goytacazes, 32 (10),1-15, 2020

seer.perspectivasonline.com.br 
- Aprova regulamento técnico sobre padrões microbiológicos para alimentos. Publicação: D.O.U. - Diário Oficial da União; Brasília, DF, 10 jan. 2001. Disponível em:http://portal.anvisa.gov.br/documents/33880/2568070/RDC_12_2001.pdf/15ffddf6-37674527-bfac-740a0400829b. Acesso em: 11 abr. 2017.

ANVISA - AGÊNCIA NACIONAL DE VIGILÂNCIA SANITÁRIA. Resolução RDC no 275 Aprova regulamento técnico sobre padrões microbiológicos para alimentos. Publicação: D.O.U. - Diário Oficial da União; Brasília, DF, 10 jan. 2001. Disponível em:http://portal.anvisa.gov.br/documents/33880/2568070/RDC_12_2001.pdf/15ffddf6-37674527-bfac-740a0400829b. Acesso em: 11 abr. 2017.

BAIA, F.P.; ORRU, H.C.D.G.; MAGALHÃES, P.P.; MENDES, S.S. Análise de métodos de produção de Shiitake no Distrito Federal. Agro em questão: Revista de Iniciação Científica da Faculdade CNA, v. 1 n. 1.1, p. 27-149. 2017.

BALBI, M.E.; FABENI, F.; LAZINSKI, L.M.; MELO, A.C.S.; SOUZA, H.F. Análise nutricional e perfil aminoacídico de cogumelos shitake (Lentinus edodes, Agaricaceae). Visão Acadêmica, v.14, n.4, p. 49-60. 2013.

BARRETO, M.R.; ISHIKAWA, N.K.; ALBINO, U.B.; ANDRADE-NOBREGA, G.M.; PACCOLA-MEIRELLES, L.D. Insetos associados ao cultivo do cogumelo comestível Lentinula edodes (Berk.) Pegler (Agaricales: Agaricaceae) no Brasil. Semin. Ciências Biológicas e da Saúde. v.23, p.83-86. 2002.

BARROS, C. Cinco dicas para cultivar cogumelos corretamente. Disponível em: http://sfagro.uol.com.br/5-dicas-para-cultivar-cogumelos-corretamente/. Acesso em: 26 jun. 2017.

BENTO, K.B.P. Atividade antimicrobiana e composição mineral do cogumelo shiitake produzido em diferentes substratos. Dissertação (Mestrado em Microbiologia Agrícola) Universidade Federal de Viçosa, Viçosa. 2001.

BERNARDI, E.; NASCIMENTO, J. S. Cultivo de Pleurotus sajor-caju em diferentes substratos pasteurizados. Arq. Ins. Biol. v. 78, p.217-22. 2011.

BERNARDI, E.; PINTO, D.M.; COSTA, E.L.G.; NASCIMENTO, J.S. Entomofauna associada ao cultivo de Pleurotus sajor-caju (Fr.) Singer (Agaricales: agaricaceae) no município do Capão do Leão, RS, Brasil. Arq. Ins. Biol. v. 77, n. 3, p.465-469. 2010.

BETT, C.F. Cultivo artesanal do cogumelo Shiitake: uma potencial atividade para agroecossistemas sustentáveis. Dissertação (Mestrado em Desenvolvimento Regional). Universidade Tecnológica Federal do Paraná. Pato Branco, PR. 2016.

BITO, T.; TENG, F.; OHISHI, N.; TAKENAKA, S.; MIYAMOTO, E.; SAKUNO, E.; TERASHIMA, K.; YABUTA, Y.; WATANAB, F. Characterization of vitamin B12 compounds in the fruiting bodies of shiitake mushroom (Lentinula edodes) and bed logs after fruiting of the mushroom. Mycoscience, v.55, p.462-468. 2014.

BONONI, V. L.; CAPELARI, M.; MAZIERO, R. Cultivo de cogumelos comestíveis. São Paulo: Ícone, 1995. 206 p.

BORGES, E.M.J. Avaliação das boas práticas de fabricação de conservas de champinnon (Agaricus bisporus (Lange) Singer) produzidas na região metropolitana de Curitiba. 
Dissertação (Mestrado em Tecnologia de alimentos). Universidade Federal do Paraná.2010. $195 p$.

CARNEIRO, H.S. Comida e Sociedade: significados sociais na história da alimentação. História: Questões \& Debates, n. 42, 71-80 (2005).

CARRAZZA, L.R.; MACIEL, L.G.; BORGES, M.C.; CORDEIRO, A.C.R.; ÁVILA, J.C.C. Caderno de normas fiscais, sanitárias e ambientais para regularização de agroindústrias comunitárias de produtos de uso sustentável da biodiversidade.2011. 67p.

CAVADA, C.A.; CARDOSO, F.M. Comparação de três metodologias para quantificação de Salmonella sp. em efluentes de sistemas de tratamento de dejetos. Acta Scientiae Veterinariae, v. 38, n. 1. p17-23. 2010.

CHAGAS, A.L.K.; FERNANDES, G.S.T. Qualidade microbiológica do camarão Macrobrachium amazonicum comercial. Perspectivas Online: Biológicas \& Saúde, v. 9, n 30, p.38-49, 2019.

DHINGRA, O.D.; SINCLAIR, J.B. Basic plant pathology methods. 2. ed. Boca Raton: CRC Press, 1995. 434p.

DUPRAT, L.A., CONTE, A.C. Produção de cogumelos por meio de tecnologia chinesa modificada. Embrapa Recursos Genéticos e Biotecnologia (Documento 263), 39p. 2008.

EMBRAPA - Embrapa abre inscrições para o $4^{\circ}$ Curso de Cultivo de Cogumelos Comestíveis e Medicinais. Disponível na Internet via: https://www.embrapa.br/web/portal/busca-de-noticias/-noticia/21521799/embrapa-abreinscricoes-para-o-49-curso-de-cultivo-de-ogumelos-comestiveis-e-edicinais. Acesso em: 26 de jul de 2017.

ERICKSON, R. Alergia a cogumelo shiitake. Disponível em: http://www.ehow.com.br/alergia-cogumelo-shiitake-info_385419/. Acesso em: 17 jul. 2017.

FINIMUNDY, T.C.; DILLON, A.J.P.; HENRIQUES, J.A.P.; ELY, M.R.A Review on General Nutritional Compounds and Pharmacological Properties of the Lentinula edodes Mushroom. Food Nutr. Sci, v. 5, p.1095-1105. 2014.

FREIRE, M.G.M.; MUSSI-DIAS, V.; COUTINHO, H.S.; HERNANDEZ, G.A.F.; TAVARES, L.P.S. Bioprospecção da flora fúngica endofítica da Reserva de Jurubatiba. Perspectivas Online: biológicas \& saúde, v.21, n.6, p.6-13, 2016.

FURLANI, R.P.; GODOY, H.T. Valor nutricional de cogumelos comestíveis: uma revisão Nutritional value of edible mushrooms: a revision. Rev. Inst. Adolfo Lutz, v. 64, p.149-154. 2005.

FURLANI, R.P.Z.; GODOY, H.T. Valor nutricional de cogumelos comestíveis. Ciênc. Tecnol. Aliment., v. 27, n. 1, p.154-157. 2007.

GONÇALVES, J.M. Espécies comestíveis de cogumelos: perfil mineral, bioacumulação de metais e preparo de material de referência certificado. Dissertação (Doutorado em Vigilância Sanitária). Rio de Janeiro: INCQS/FIOCRUZ, 2012. 99p.

HAAS, L. Noções básicas para um estudo de vida vegano e saudável: como viver sem 
carne e sem laticínios. Babelcube Inc. 2016. 69p.

KADO, C.I.; HESKETT, M.G. Selective media for isolation of Agrobacterium, Corynebacterium, Erwinia, Pseudomonas and Xanthomonas. Phytopathology, v. 60, n. 6, p. 969-976, 1970.

KUSHIDA, M. M. Validação de métodos laboratoriais: avaliação do sistema bax® de análise de Salmonella sp em alimentos por reação de polimerase em cadeia (PCR). Dissertação (Doutorado em Ciência de Alimentos). Campinas: UNICAMP. 2005. 165p.

MAPA - MINISTÉRIO DA AGRICULTURA, DO ABASTECIMENTO E DA REFORMA AGRÁRIA. Método analítico de carcaça de aves e pesquisa de Salmonella. 1995. Disponível em: http://www3.servicos.ms.gov.br/iagro_ged/pdf/423_GED.pdf. Acesso em: 12 jun. 2017.

MIWA J. Sem crueldade animal! Conheça o couro biodegradável feito de cogumelo. 2016. Disponível em: http://thegreenestpost.bol.uol.com.br/conheca-o-couro-do-futuro-quesera-feito-de-cogumelo/. Acesso em: jul. 2017.

MIZUNO, T.; SAKAI, T.; CHIHARA, G. Health foods and medicinal usages of mushrooms. Food Reviews International. v. 11, n. 1, p. 69-81, 1995.

MODA, E.M. Aumento da vida útil de cogumelos Pleurotus sajor-cajuin natura com aplicação de radiação gama. Dissertação (Doutorado em Ciências). Piracicaba: USP. 2008. $105 \mathrm{p}$.

MOURA, AP.B.L.; PINHEIRO JUNIOR, J.W.; OLIVEIRA, R.B.A.; DUARTE, D.A.M.; RIBEIRO, A.R.; REIS, E.M.F. Reis. Pesquisa de coliformes termotolerantes, totais, e Salmonella spp. em carnes caprinas comercializadas na cidade do Recife, Pernambuco. Arq. Inst. Biol, v.74, 293-299. 2007.

ORTIZ, C.H.; GANNONE, D.O. Fatores competitivos brasileiros que influenciam a internacionalização do cogumelo Agaricus blazei para o Japão. Portal Mackenzie.ano IV.n.6, 2007.

PAULO, E.M. Manual da disciplina: microbiologia de alimentos. 2005. Disponível em: $w$ ww.ccta.ufcg.edu.br/admin.files.action.php?action=download\&id=388. Acesso em: 25 jun. 2017.

ROMEIRO, R.S. Métodos em bacteriologia de plantas. 1.ed. Viçosa: Editora UFV, 2001. v.1, 279p.

ROSA, L.H. Colheita e processamento de cogumelos comestíveis e medicinais para comercialização. Fundação Centro Tecnológico de Minas Gerais - CETEC. 2007. 16p.

RUEGGER, M.J.S., TORNISIELO, S.M.T., BONONI, V.L.R., CAPELARI, M. Cultivation of the edible mushroom Oudemansiella canarii (jungh.) Höhn. In lignocellulosic substrates. Brazilian Journal of Microbiology, v. 32, 211-214, 2001.

SAMPAIO, S.M.; QUEIROZ, M.R. Influência do processo de secagem na qualidade do cogumelo Shiitake. Eng. Agríc., v.26, n.2, p.570-577, 2006.

SÁNCHEZ-MINUTTI, L.; TÉLLEZ-TÉLLEZ, M.; TLECUITL-BERISTAIN, S.; SANTOS- 
LÓPEZ, G. Antimicrobial activity of a protein obtained from fruiting body of Lentinula edodes against Escherichia coli and Staphylococcus aureus. Journalof Environmental Biology, v. 37, 619-623,2016.

SANTOS, D.M.S.; JUNIOR, A.B.; FERNANDES, S.A.; TAVECHIO, A.T.; AMARAL, L.A. Salmonella em carcaças de frango congeladas. Pesquisa Veterinária Brasileira, v.20, n.1, p.39-42, 2000.

SEBRAE. Para início de negócio: cultivo de cogumelo. Sebrae/MG. 2005. 67p.

SEIFERT, K.; MORGAN-JONES, G.; GAMS, W.; KENDRICK, B. The Genera of Hyphomycetes. CBS Biodiversity Series no. 9: 1-997. CBS-KNAW Fungal Biodiversity Centre, Utrecht, Netherlands. 2011.

SILVA, N.; JUNQUEIRA, V.C.A.; SILVEIRA, N.F.A.; TANIWAKI, M.H.; SANTOS, R.F.S.; GOMES, R.A.R.; OKAZAKI, M.M. Manual de métodos de análise microbiológica de alimentos e agua. São Paulo: Logomarca Varela. $3^{\text {a }}$ ed. 2007.

SOUZA, J.M.L.; CARTAXO, C.B.C.; LEITE, F.M.N.; REIS, F.S. Avaliação icrobiológica de amêndoas de castanha-do-brasil em usinas de beneficiamento no Acre. Boletim de Pesquisa e Desenvolvimento, 39. 2004. 24p.

TIHOHOD, D. Nematologia agrícola aplicada. 1. Jaboticabal. Funep. 1993.

URBEN, A.F. Consumo de cogumelos cresce no Brasil. 2014. Disponível em: http://www.canalrural.com.br/videos/rural-noticias/consumo-cogumelos-cresce-brasil-32900. Acesso em: 26 jul. 2017.

URBEN, A.F. Produção de cogumelos por meio de tecnologia chinesa modificada. Brasília: Embrapa, 2004. 186 p.

VARGAS, A.M. Análise diagnóstica da cadeia produtiva de cogumelos do Distrito Federal. Dissertação (Mestrado em Agronegócios). Universidade de Brasília - Fac. Agron. e Med. Veterinária. 2011. 130p.

VEIGA S.M.O.M.; NASCIMENTO, L.C.; CARVALHO, P.L.N. Apostila de aulas práticas de microbiologia ambiental. Alfenas: UNIFAL. 2013. 55p. 